BACTERIOLOGICAL NOMENCLATURE $A N D$

T A XONOMY

Volume $4 \quad$ October 15,1954

Nos. 3-4

THE PROBLEM OF THE NOMENCLATURE OF BACILLUS SUBTILIS AND BACILLUS VULGATUS

\title{
Carl Lamanna
}

Department of Microbiology, The Johns Hopkins

School of Hygiene and Public Health, Baltimore, Maryland

At the Second International Congress for Microbiology (1936) the International Committee on Bacteriological Nomenclature established Bacillus subtilis Cohn emend. Prazmowski as the type species of the genus Bacillus. The action based on the study by Conn (1930) was followed by the selection of the small-celled B. subtilis Marburg strain in Conn's collection as the type cullture of the species. Following the Congress two reports appeared indicating that in fact two small-celled species were masquerading in culture collections as $\underline{B}$. subtilis, (Gibson, 1937; Lamanna, 1940). The Marburg strain selected as the type culture is identical with strains in collections labeled B. vulgatus (Lamanna, 1940).

Succeeding reports by Burdon, Stokes, and Kimbrough (1942), Gibson (1944), and Knaysi and Gunsalus (1944) agreed with the conclusion that the small-celled species Bacillus subtilis was separable into two species. In an initial study Smith, Gordon, and Clark (1944) did not separate $B$. subtilis into two species. Upon further study and reflection these investigators reversed their position (1952). Consequently at the present time there is unanimous agreement among students of the problem since Conn's time (1930) that the two different species are represented by the $B$. subtilis Marburg strain and the B. subtilis identified by Lawrence and Ford (1916). These developments make pertinent the present reexamination of the scientific merit of accepting the Marburg strain as the type culture of $B$. subtilis Cohn emend. Prazmowski. Page 133) 
Inasmuch as the Marburg strain is identical with the organism known in the past as B. vulgatus (Lamanna, 1940, 1942; Gibson, 1944; Smith et al., 1952) the designation of the Marburg strain as the type culture of $B$. subtilis requires the rejection of the name $\underline{B}$. vulgatus and the validation of a new name for the other small-celled organism in culture collections called B. subtilis. Gibson (1944) and Smith et al. (1942) have suggested the retention of the Marburg strain as type strain, have placed $B$. vulgatus as a synonym of $B$. subtilis and designated B. licheniformis (Weigmann) Gibson as the valid name of the organism represented by the Lawrence and Ford strain of $B$. subtilis. The discussion that follows attempts to judge the scientific merit of these suggestions.

The designation by the International Committee of Bacteriological Nomenclature of $\underline{B}$. subtilis Cohn emend. Prazmowski as type species logically required the selection as type culture of a culture originating in Prazmowski's study, provided one were available. Documentary evidence is lacking to prove such an origin for the Marburg strain or any other existing culture. Therefore, the selection of the Marburg strain as type culture can only rest on proof that this culture more closely fits Prazmowski's description of the organism he called B. subtilis than other possible candidates. Sad to relate Prazmowski's description is inadequate by current standards. Prazmowski provided no series of presently accepted significant diagnostic characteristics which can be employed for the comparative study of strains. He did record pictorially the method of spore germination of his organism. These drawings sufficiently impressed themselves upon the minds of contemporaries and a succeeding generation of bacteriologiste to have led to their reproduction a large number of times in textbooks and the inclusion of the statement in manuals of determinative bacteriology of an equatorial mode of germination of spores as a characteristic of $\underline{B}$. subtilis.

Lamanna (1940), and Knaysi and Gunsalus (1944) have called attention to two distinct modes of equatorial germination, germination with and germination without splitting of the spore case along the transverse axis. They believe these differing modes of germination to be of diagnostic value in the identification of small-celled species. During germina- 
tion the Marburg strain characteristically splits the spore case, while the $B$. subtilis of the Lawrence and Ford type does not. In personal communications Prof. K. L. Burdon of Baylor University has indicated his ability to corroborate these observations in his as yet unpublished taxonomic studies of the aerobic spore-formers. The method of germination illustrated by Prazmowski appears to be equatorial without splitting of the spore case along the transverse axis. Therefore, with respect to the one definite characteristic we can associate with Prazmowski's organism the Marburg strain is dissimilar, the Lawrence and Ford type similar. This finding casts serious doubt on the validity of accepting the Marburg strain as the type culture of $B$. subtilis in preference to a culture of the Lawrence and For $\overline{\mathrm{d} \text { train. }}$

Gibson (1944) who published befare the paper by Knaysi and Gunsalus appeared (1944) questioned the value of observations of modes of spore germination, particularly for purposes of routine diagnosis. Smith et al. (1952) who do not refer to the paper by Knaysi and Gunsalus have been satisfied with the acceptance of the Marburg strain as the type culture. In 1944 they did not believe the mode of spore germination sufficiently stable a character to be of taxonomic value.

\footnotetext{
${ }^{1}$ As one who has studied the cytology of spore germination of many strains for a number of years, I have been impressed by spore germination as a process, not as a still picture. One must follow the birth of the new regetative organism from the moment the spore $10 s e s$ its impermeability to dya and begins to bulge slightly to the time when the new organism undergoes fission. It is by studying the succession of appeam ances during the process and not by a glance at a particular moment in germination that one learns to appreciate the beautiful and consistent differences that exist between species. In the process of splitting of the spore case along the transverse axis, dependent upon how the new organism emerges from the spore case, the separated halves of the spore case may snap back toward each other. This is prone to happen when the emerging organism leaves the spore case at about $90^{\circ}$ to the longitudinal axis, and may leave one with the false impression of germination without splitting along the transverse axis, if the action has not been followed from the beginning.
} 
Knaysi and Gunsalus (1944) the only investigators who have studied spore germination in parent and dissociant cultures of the Marburg and Lawrence and Ford strains do not agree with these views. They found no differences in the modes of germination of dissociants from parent cultures. They could regularly determine and distinguish between the modes of germination of the two species.

If the point of view were to be accepted that the mode of germination is a valueless diagnostic character, the one definable characteristic possessed by Prazmowski's organism is declared taxonomically useless, and the wisdom of selection of Prazmowski's organism as a type species is placed in question. Possibly the decision to accept Prazmowski's or ganism may have been an unwise one, but this consideration is neither pro nor con in any defence of the choice of the Marburg strain as type culture. As long as the ruling remains that Prazmowski's organism is the type species of the genus Bacillus the type culture must be the one most closely resembling the original description. The Marburg organism is not the best choice since the Lawrence and Ford kind of organism resembles Prazmowski's picture of spore germination more closely.

If the Marburg strain is rejected as a true example of $B$. subtilis Cohn emend. Prazmowski it would appear to be proper to call this organism $B$. vulgatus (Flügge) Trevisan. This conclusion is based on the compilations of Gibson (1944) and Smith et al. (1952) of the names other than subtilis that have been affixed to organisms like the Marburg strain. Flugge (1886) would appear to be the first to have adequately studied this organism, but since he employed the trinomial B. mesentericus vulgatus, Trevisan's (1889) binomial $\underline{B}$. vulgatus has priority.

If the Lawrence and Ford strain is rejected as an example of Prazmowski's B. subtilis a new name must be found for this organism. Gibson (1944) and Smith et al. (1952) have suggested $\underline{B}$. licheniformis (Weigmann) Chester, a questionable choice. The identity of Weigmann's organism is obscure since its characterization is based almost entirely on cultural appearances of growth, properties whichare now known to be greatly subject to dissociation and to subtle variations 
in environment. It is extremely doubtful that Weigmann's organism is the $B$. subtilis represented by the Lawrence and Ford strain. Weigmann was so impressed with the swelling of the mother cell during sporulation of his organism that he placed his organism in the genus Clostridium, a genus not defined in his day as being constituted of anaerobes alone. Clostridium was employed by Weigmann and other bacterial taxonomists of his day to describe spindle-shaped sporulating organisms. The word clostridium is derived from the Greek and means little spindle. Chester who was familiar in 1901 with Weigmann's work recorded $B$. licheniformis as having "clavate forms at sporulation." Now both Gibson and Smith et al. place their B. licheniformis (Weigmann) in their keys undér organisms whose "spores produce little or no swelling of sporangium" (Gibson), "sporangia only slightly swell if at all" (Smith et al.). Furthermore Weigmann recorded polar germination for his $C$. licheniforme, while everyone agrees that spore germination of the Lawrence and Fordstrain is not polar. There are other points of disagreement between the descriptions of Weigmann, and Gibson and Smith et al. Since Weigmann was interested in $\mathrm{C}$. licheniforme $\bar{b} e \bar{c}$ ause of its possible effects on cheese ripening it is particularly pertinent to recall that he recorded the development of a neutral or alkaline reaction upon growth in milk. Contrarily Gibson recorded the development of slight acidity for the strains he studied.

In authoritative determinative bacteriology manuals that approximate in time the original naming of the spore-formers under consideration such as Migula (1900), Chester (1901), and Lehmann and Neumann (1901) B. subtilis and B. vulgatus (B. mesentericus vulgatus) were recognized as two species. The organism C. licheniforme Weigmann is mentioned in these texts but apparently was not considered worthy enough to belisted as a well-defined species. Now it would be reasonable to believe that if work in more recent times reaffirms the existence of two species, the oldest names accepted by the earlier taxonomists should be seriously considered as appropriate organisms. 


\section{CONCLUSIONS}

The Lawrence and Ford strain of $B$. subtilis more closely resembles Prazmowski's B. subtilis than the Marburg culture. This finding should invalidate the choice of the Marburg strain as the type culture of $B$. subtilis Cohn emend. Prazmowski.

The Marburg strain is an example of $\underline{B}$. vulgatus (Flügge) Trevisan.

It is improbable that the Lawrence and Ford type of B. subtilis is a representative of the organism named Clostridium licheniforme by Weigmann.

\section{PROPOSAL}

The Judicial Commission is asked to reconsider the designation of the Marburg strain as the type culture of B. subtilis Cohn emend. Prazmowski.

\section{REFERENCES}

Burdon, K.L., J.C. Stokes and C.E. Kimbrough. Studies of the common aerobic spore-forming bacilli. II. Fermentation reactions in agar butt-slants. J. Bact. 44:163, 1942 .

Chester, F.D. A Manual of Determinative Bacteriology. New York, 1901.

Conn, H.J. The identity of Bacillus subtilis. J. Infect. Dis. 46:341. 1930 .

Gibson, $T$. The identity of Bacillus subtilis and its differentiation from other spore-forming bacteria. Soc. Agr. Bact. Proc. Abs. 1937.

A study of Bacillus subtilis and related organisms. J. Dairy Res. 13: $\overline{: 48.1944 .}$

Knaysi, G., and L. C. Gunsalus. A study of the so-called Marburg and the Lawrence strains of Bacillus subtilis. J. Bact. 47:381. 1944 .

Lamanna, C. The taxonomy of the genus Bacillus. I. Modes of spore germination. J. Bact. 40:347.1940.

The taxonomy of the genus Bacillus. II. Differentiation of small-celled species by means of spore antigens. J. Infect. Dis. 67:193. 1940 . 
The status of Bacillus subtilis, including a note on the separation of precipitinogens from bacterial spores. J. Bact. 44:611, 1942 .

Lehmann. K.B., and R. O. Neumann. Atlas and principles of bacteriology. Part II (Translated from vol. 2, German edition) W.B. Saunders and Co., Philadelphia, $\bar{P}_{2} .1901$. Migula, W. Vol. 2. System der Bakterien. Jena. 1900.

Prazmowski, A. Untersuchungen über die Entwicklungsgeschichte und Fermentwirkung einiger Bacterium-Arten. Inaug. Diss. Leipzig, 1880.

St. John-Brooks, and R.S. Breed. Actions taken by the Second International Congress Microbiological. (1936) J. Bact. 33:445, 1937 .

Smith, N.R., R.E. Gordon, and F.E.Clark. Aerobic sporeforming bacteria. U.S.D.A. Misc. Publ. 559, 1944.

Monograph No. 16 , U.S.D.A. 1952 .

Trevisan, V. I generi e le specie delle Bacteriacee. Milan, 1889. Reprint in Int. Bull. Bact. Nom. and Tax. 2(1):1344. 1952 .

Weigmann, H. Ueber zwei an der Käsereifung beteiligte Bakterien. Centbl. f. Bakt. Abt. 2, 4 :820. 1898. 